\title{
Scenario Forecasting Tourist Flows during the COVID-2019 Pandemic
}

\author{
Olga Zaborovskaia ${ }^{1 *}$, Elena Sharafanova², Liudmila Maksanova ${ }^{3}$
}

${ }^{1}$ The State Institute of Economics, Finance, Law and Technology, Roschinskaya Street, 5, Gatchina, Leningrad region 188300, Russia

${ }^{2}$ St. Petersburg State University of Economics, Sadovaya Street, 21, Saint-Petersburg 191023, Russia

${ }^{3}$ The Baikal Institute of Nature Management of the Siberian branch of the Russian Academy of Sciences, Sakhyanov Street, 6, Ulan-Ude, Republic of Buryatia 670047, Russia

\begin{abstract}
The purpose of the study is to obtain a scenario forecast of the volume and rate of recovery in tourist flows, which have experienced a catastrophic decline due to restrictions imposed by the COronaVirus Disease 2019 (COVID-19) threats. As a forecasting tool in conditions of insufficient initial analytical data, it is proposed to use a model based on the extrapolation of tourist flows. The forecasts were made for Russian regions included in the Interregional Association for Economic Cooperation "The Siberian Agreement". The research results are presented in the form of four forecast scenarios calculated in the rough forecast methodology under various hypotheses about changing the input parameters of the model.
\end{abstract}

Keywords: Forecasting; Pandemic; Recovery of tourist flows; Tourism industry

\section{Introduction}

The COVID-19 pandemic struck a devastating blow to the tourism industry around the world. According to Federal Agency for Tourism estimates, in May 2020, the fall in turnover in this sector was 95-100\%, the lost income exceeded 1.5 trillion rubles, and about 2.5 million tourism workers were threatened by unemployment (Berawi, 2020; Berawi et al., 2020; Losses, n.d.).

Prediction of the possibility of restoring tourist flows is the first step in forming algorithms of actions, their financial support, and mechanisms of their neutralization. Therefore, the aim of this paper is determined by the need to develop forecasts of consumption of tourist products under conditions of the poor predictability of tourist flows and severe external restrictions on meeting the demand for consumption of tourist products. T. The problem in this case is to evaluate the choice of input parameters of the predictive model of scenarios, which allows taking into consideration different variants of gradual fading of the pandemic.

The study is based on the concept of a rough forecast, which makes it possible to assess the general trends in the development of the industry in conditions of a high degree of uncertainty of environmental factors. Predictive calculations are implemented on the data of several subjects of the Siberian Federal District, included in the Interregional Association for Economic Interaction of the Subjects of the Russian Federation's Siberian Agreement. 


\section{Methods}

Regression models are often used to predict revenues from tourist services and flows of consumers of tourist products (Aitzhanova, 2015). Attempts to use game theory for making strategic decisions and forecasting profits from tourist services depending on the state of the environment are of some interest, although this is relatively theoretical (Belinskaya and Chaikovskaya, 2017). However, in recent years, serious research has increasingly emerged based on the inability to use traditional statistical methods for forecasting processes and phenomena occurring under poorly predictable or completely unpredictable factors (Minaev et al., 2015; LeBlanc, 2020). This is due to the apparent unreliability of predictions (Kirillova and Chernukha, 2017).

The unreliability of long-term forecasts is aggravated by the incomplete and narrow statistical base of forecasting. The request of the tourism industry to establish end-to-end project management based on business analytics of big data also requires the use of forecasting methods adequate to the pace of change in the industry's external and internal environments (Pershina and Daragan, 2018; Pradita et al., 2020). Requests of this kind are satisfied, for example, via accessible services, such as those of Forecasts of International Traveler Activity (Forecasts, 2020), a reference panel on tourism forecasting that includes experts from the industry and government.

The main publications on the impact of COVID-19 on tourism by summer 2020 relate to assessing the depth of industry decline and the amounts of losses. The problem of assessing the rate and timing of the recovery of a pre-crisis level of tourist flows has not yet been presented sufficiently in the professional literature.

Development of a scenario forecast in conditions of poor predictability and uncertainty is based on the concept of a rough forecast, which allows forecast estimates to be obtained that are accurate to the trend. This approach requires periodic adjustments of forecast values until the process becomes predictable.

Prediction of tourist flow dynamics in connection with the coronavirus pandemic can be based on scarce factual data, such as the following:

- The period of quarantine, with epidemiological measures and effective actions of government agencies and the healthcare system, is approximately 2.5 months (according to the experience of China P); and

- During the period of strict quarantine measures, inbound tourism is prohibited, and domestic tourism is strictly limited.

In the summer of 2020 tourist flows were not exceed $20-50 \%$ of the pre-crisis level of 2019 (according to the Federal Agency for Tourism of the Russian Federation, by early April 2020, the fall in sales in the tourism sector of Russia had reached 90-100\%). Further developments may be presented by the scenarios described below.

- Scenario 1 (extremely pessimistic). Second wave of the pandemic in winter 20202021, closure of international borders, severe restrictions on interregional movements of citizens, lifting restrictions by summer 2021 and gradual (uniform) restoration of the tourist flow to the level of 2019 by 2025 (decrease in the tourist flow in 2020 as compared with 2019: 80\%).

- Scenario 2 (pessimistic). Initial conditions are similar to scenario 1 but stimulating measures to restore international and domestic tourism will restore tourist flows to the level of 2019 by 2023 , with subsequent growth within the average rate for the five years preceding the pandemic (2015-2019).

- Scenario 3 (moderate). Gradual fading of the pandemic in winter/spring 2021, restoration of domestic tourism in spring 2020-2021, restoration of inbound tourism in summer 2021. Decrease of tourist flow by $50 \%$ in 2020 compared to 2019, restoring 
it to the level of 2019 by 2023 with subsequent growth within the average annual growth rate for the five years preceding the pandemic (2015-2019).

- Scenario 4 (positive). End of the pandemic in winter 2020-2021, lifting severe restrictions on international travel, restoration of inbound and domestic tourism in winter 2020. The pressure of deferred demand for recreation will ensure accelerated growth of tourist flows in the winter, so that in general, in 2020, their decline will be $20 \%$ with subsequent growth to the level of 2019 in 2023 and subsequent linear growth.

Testing the methodology was carried out on the data on tourist flows of the constituent entities of the Russian Federation-members of the Interregional Association of the Economic Cooperation of the Constituent Entities of the Russian Federation's "Siberian Accord" (IASA). Currently, the regions covered by IASA, as well as the Republic of Buryatia and the Transbaikal Region, are members of the accord. The Tyumen Region and the Khanty-Mansi Autonomous Area/Yugra cooperate with IASA on certain issues. In November 2019, the Board of IASA adopted the concept of a comprehensive investment project "Development of Domestic and Inbound Tourism in Siberia (2019-2025)," implementation of which will ensure an increase in tourist flow in the regions of IASA up to 10 million people, a $30 \%$ increase in the number of employees in the tourism sector, and a growth of paid services by 1.9 times e. However, under the conditions of the coronavirus pandemic, considering a sharp decline in tourist flow, closure of all tourist destinations, reduction of business activities, and growth of unemployment in tourism and related industries, there is a need to adjust the forecast.

Accepted designations are as follows: $\mathrm{P}(\mathrm{t})$ is a tourist flow in period $\mathrm{t}$ (according to Table 1), $\mathrm{P}(\mathrm{t} \Pi)$ is a projected tourist flow in period $t$, and $\mathrm{I}$ is the average compound of chain indices of tourist flow growth for the period of 2015-2019.

\section{Results and Discussion}

\subsection{Scenario 1 (extremely pessimistic)}

Calculation algorithm:

$$
\begin{gathered}
P(2020)=P(2019) * 0.2 \\
P(t+1)=P(t)+(P(2019)-P(2020)) / 5
\end{gathered}
$$

Table 1 Forecast for the size of the tourist flow in the constituent entities of the Russian Federation-members of IASA until 2025 (extremely pessimistic scenario), thousands of

\begin{tabular}{|c|c|c|c|c|c|c|c|}
\hline Region & 2019 & 2020 & 2021 & 2022 & 2023 & 2024 & 2025 \\
\hline Russian Federation & 68283.89 & 13656.78 & 24582.20 & 35507.62 & 46433.05 & 57358.47 & 68283.89 \\
\hline Altai Republic & 193.41 & 38.68 & 69.63 & 100.57 & 131.52 & 162.46 & 193.41 \\
\hline Republic of Buryatia & 365.92 & 73.18 & 131.73 & 190.28 & 248.82 & 307.37 & 365.92 \\
\hline Tyva Republic & 35.62 & 7.12 & 12.82 & 18.52 & 24.22 & 29.92 & 35.62 \\
\hline $\begin{array}{l}\text { Republic of } \\
\text { Khakassia }\end{array}$ & 163.63 & 32.73 & 58.91 & 85.09 & 111.27 & 137.45 & 163.63 \\
\hline Altai Region & 669.03 & 133.81 & 240.85 & 347.90 & 454.94 & 561.99 & 669.03 \\
\hline Transbaikal Region & 214.16 & 42.83 & 77.10 & 111.36 & 145.63 & 179.89 & 214.16 \\
\hline Krasnoyarsk Region & 743.03 & 148.61 & 267.49 & 386.38 & 505.26 & 624.15 & 743.03 \\
\hline Irkutsk Region & 885.06 & 177.01 & 318.62 & 460.23 & 601.84 & 743.45 & 885.06 \\
\hline Kemerovo Region & 569.13 & 113.83 & 204.89 & 295.95 & 387.01 & 478.07 & 569.13 \\
\hline Novosibirsk Region & 1008.18 & 201.64 & 362.95 & 524.25 & 685.56 & 846.87 & 1008.18 \\
\hline Omsk Region & 522.42 & 104.48 & 188.07 & 271.66 & 355.25 & 438.84 & 522.42 \\
\hline Tomsk Region & 236.36 & 47.27 & 85.09 & 122.91 & 160.72 & 198.54 & 236.36 \\
\hline
\end{tabular}
people 


\begin{tabular}{lccccccc}
\hline \multicolumn{1}{c}{ Region } & \multicolumn{1}{c}{2019} & 2020 & 2021 & 2022 & 2023 & 2024 & 2025 \\
\hline Tyumen Region & 749.36 & 149.87 & 269.77 & 389.67 & 509.57 & 629.47 & 749.36 \\
\hline $\begin{array}{l}\text { Khanty-Mansi } \\
\text { Autonomous Area }\end{array}$ & 578.40 & 115.68 & 208.22 & 300.77 & 393.31 & 485.86 & 578.40 \\
\hline Total in IASA & 7229.98 & 1446.00 & 2602.79 & 3759.59 & 4916.39 & 6073.19 & 7229.98 \\
\hline $\begin{array}{l}\text { Total in Siberian } \\
\text { Federal District }\end{array}$ & 5846.09 & 1169.22 & 2104.59 & 3039.97 & 3975.34 & 4910.72 & 5846.09 \\
\hline
\end{tabular}

Dynamics of tourist flows according to this forecast scenario are shown in Figures 1 and 2.

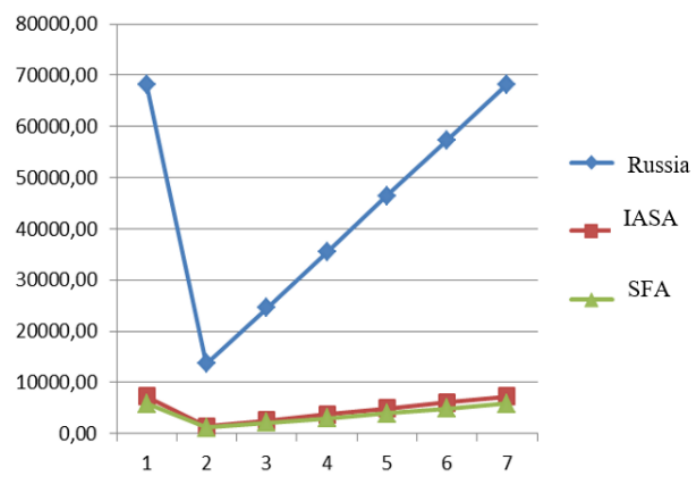

Figure 1 Forecast dynamics of tourist flows in Russia, Siberian Federal Areal (SFA) SFD, and IASA, 2019-2025 (extremely pessimistic scenario)

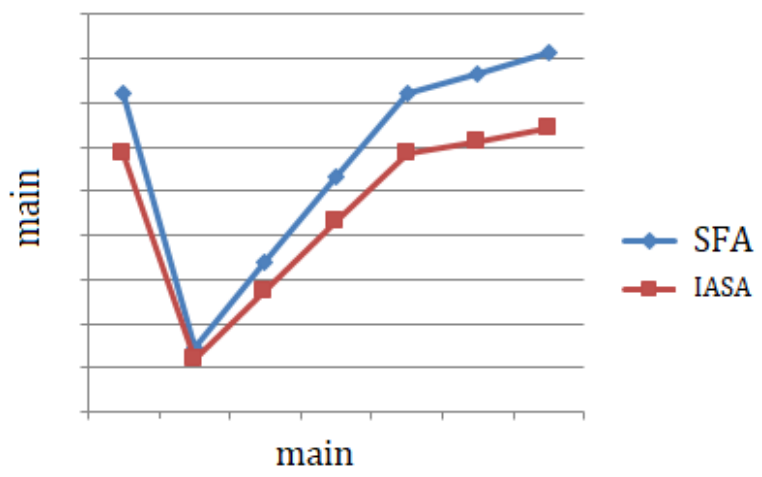

Figure 2 Dynamics of tourist flows in SFA and IASA, 2019-2025 (extremely pessimistic scenario)

\subsection{Scenario 2 (pessimistic)}

Calculation algorithm:

$$
\begin{gathered}
P(2020)=P(2019) * 0.2 \\
P(t+1)=P(t)+(P(2019)-P(2020)) / 3 \text { (for flows in 2021, 2022, 2023) } \\
P(t+1)=P(t) * I
\end{gathered}
$$

An exception was made for the Irkutsk region: The average annual growth rate for 20152019 for this entity was 0.976 , so the growth index was taken as 1.0 in the forecast (Table 2). and 4 .

Dynamics of tourist flows according to this forecast scenario are shown in Figures 3

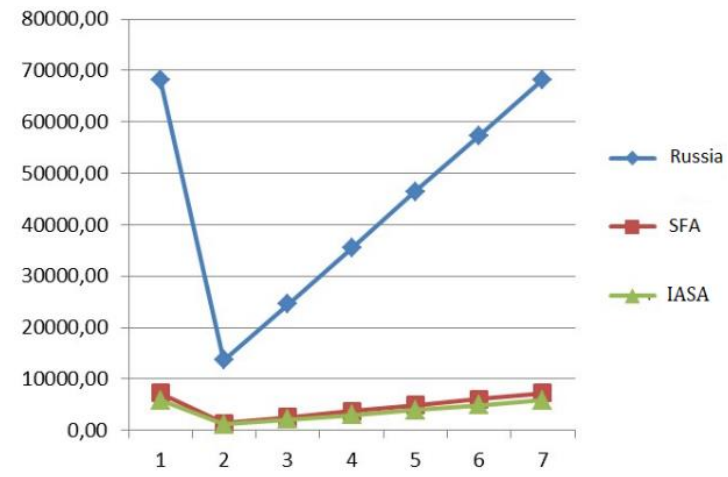

Figure 3 Dynamics of tourist flows in Russia, SFA, and IASA, 2019-2025 (pessimistic scenario)

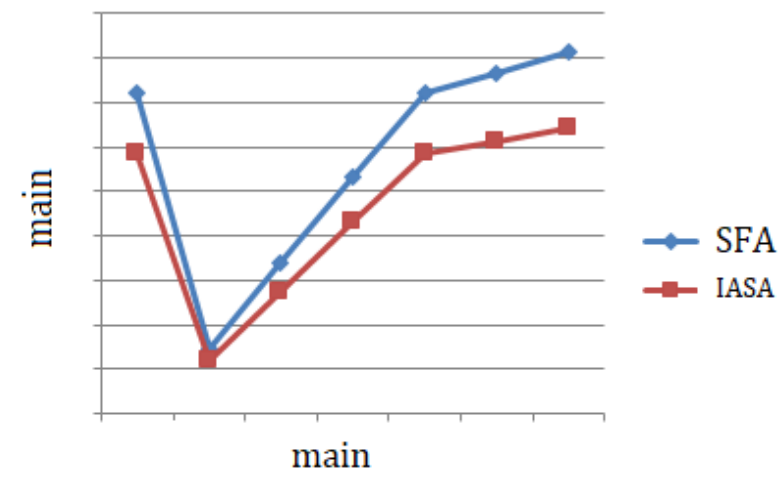

Figure 4 Dynamics of tourist flows in SFA and IASA, 2019-2025 (pessimistic scenario) 
Table 2 Forecast for the size of the tourist flow in the constituent entities of the Russian Federation-members of IASA until 2025 (pessimistic scenario), thousands of people

\begin{tabular}{|c|c|c|c|c|c|c|c|c|}
\hline Region & 2019 & 2020 & 2021 & 2022 & 2023 & 2024 & 2025 & $\begin{array}{r}\text { Average } \\
\text { growth } \\
\text { index } \\
2015- \\
2019\end{array}$ \\
\hline $\begin{array}{l}\text { Russian } \\
\text { Federation }\end{array}$ & 68283.89 & 13656.78 & 31865.82 & 50074.85 & 68283.89 & 74083.39 & 80375.46 & 1.085 \\
\hline Altai Republic & 193.41 & 38.68 & 90.26 & 141.83 & 193.41 & 196.11 & 198.85 & 1.014 \\
\hline $\begin{array}{l}\text { Republic of } \\
\text { Buryatia }\end{array}$ & 365.92 & 73.18 & 170.76 & 268.34 & 365.92 & 376.84 & 388.10 & 1.030 \\
\hline Tyva Republic & 35.62 & 7.12 & 16.62 & 26.12 & 35.62 & 35.74 & 35.86 & 1.003 \\
\hline $\begin{array}{l}\text { Republic of } \\
\text { Khakassia }\end{array}$ & 163.63 & 32.73 & 76.36 & 120.00 & 163.63 & 165.34 & 167.06 & 1.010 \\
\hline Altai Region & 669.03 & 133.81 & 312.21 & 490.62 & 669.03 & 671.08 & 673.14 & 1.003 \\
\hline $\begin{array}{l}\text { Transbaikal } \\
\text { Region }\end{array}$ & 214.16 & 42.83 & 99.94 & 157.05 & 214.16 & 216.47 & 218.81 & 1.011 \\
\hline $\begin{array}{l}\text { Krasnoyarsk } \\
\text { Region }\end{array}$ & 743.03 & 148.61 & 346.75 & 544.89 & 743.03 & 770.02 & 797.99 & 1.036 \\
\hline $\begin{array}{l}\text { Irkutsk } \\
\text { Region }\end{array}$ & 885.06 & 177.01 & 413.03 & 649.05 & 885.06 & 885.06 & 885.06 & 0.976 \\
\hline $\begin{array}{l}\text { Kemerovo } \\
\text { Region }\end{array}$ & 569.13 & 113.83 & 265.59 & 417.36 & 569.13 & 591.92 & 615.61 & 1.040 \\
\hline $\begin{array}{l}\text { Novosibirsk } \\
\text { Region }\end{array}$ & 1008.18 & 201.64 & 470.49 & 739.33 & 1008.18 & 1168.05 & 1353.27 & 1.159 \\
\hline Omsk Region & 522.42 & 104.48 & 243.80 & 383.11 & 522.42 & 531.07 & 539.86 & 1.017 \\
\hline $\begin{array}{l}\text { Tomsk } \\
\text { Region }\end{array}$ & 236.36 & 47.27 & 110.30 & 173.33 & 236.36 & 286.35 & 346.92 & 1.212 \\
\hline $\begin{array}{l}\text { Tyumen } \\
\text { Region }\end{array}$ & 749.36 & 149.87 & 349.70 & 549.53 & 749.36 & 846.54 & 956.32 & 1.130 \\
\hline $\begin{array}{l}\text { Khanty-Mansi } \\
\text { Autonomous } \\
\text { Area }\end{array}$ & 578.40 & 115.68 & 269.92 & 424.16 & 578.40 & 620.97 & 666.67 & 1.074 \\
\hline Total in IASA & 7229.98 & 1446.00 & 3373.99 & 5301.99 & 7229.98 & 7664.54 & 8125.22 & 1.060 \\
\hline $\begin{array}{l}\text { Total in } \\
\text { Siberian } \\
\text { Federal } \\
\text { District }\end{array}$ & 5846.09 & 1169.22 & 2728.18 & 4287.13 & 5846.09 & 6132.20 & 6432.32 & 1.049 \\
\hline
\end{tabular}

\subsection{Scenario 3 (moderate)}

Calculation algorithm:

$$
\begin{gathered}
P(2020)=P(2019) * 0.5 \\
P(t+1)=P(t)+(P(2019)-P(2020)) / 3 \text { (for flows in 2021, 2022, 2023) } \\
P(t+1)=P(t) * I
\end{gathered}
$$

An exception was made for the Irkutsk region: The average annual growth rate for 20152019 for this entity was 0.976 , so the growth index was taken as 1.0 in the forecast (Table 3). and 6.

Dynamics of tourist flows according to this forecast scenario are shown in Figures 5 
Table 3 Forecast for the size of the tourist flow in the constituent entities of the Russian Federation-members of IASA until 2025 (moderate scenario), thousands of people

\begin{tabular}{|c|c|c|c|c|c|c|c|c|}
\hline Region & 2019 & 2020 & 2021 & 2022 & 2023 & 2024 & 2025 & $\begin{array}{r}\text { Average } \\
\text { growth } \\
\text { index } \\
2015- \\
2019\end{array}$ \\
\hline $\begin{array}{l}\text { Russian } \\
\text { Federation }\end{array}$ & 68283.89 & 34141.95 & 45522.59 & 56903.24 & 68283.89 & 74083.39 & 80375.46 & 1.085 \\
\hline Altai Republic & 193.41 & 96.71 & 128.94 & 161.18 & 193.41 & 196.11 & 198.85 & 1.014 \\
\hline $\begin{array}{l}\text { Republic of } \\
\text { Buryatia }\end{array}$ & 365.92 & 182.96 & 243.94 & 304.93 & 365.92 & 376.84 & 388.10 & 1.030 \\
\hline Tyva Republic & 35.62 & 17.81 & 23.75 & 29.69 & 35.62 & 35.74 & 35.86 & 1.003 \\
\hline $\begin{array}{l}\text { Republic of } \\
\text { Khakassia }\end{array}$ & 163.63 & 81.82 & 109.09 & 136.36 & 163.63 & 165.34 & 167.06 & 1.010 \\
\hline Altai Region & 669.03 & 334.52 & 446.02 & 557.53 & 669.03 & 671.08 & 673.14 & 1.003 \\
\hline $\begin{array}{l}\text { Transbaikal } \\
\text { Region }\end{array}$ & 214.16 & 107.08 & 142.77 & 178.47 & 214.16 & 216.47 & 218.81 & 1.011 \\
\hline $\begin{array}{l}\text { Krasnoyarsk } \\
\text { Region }\end{array}$ & 743.03 & 371.52 & 495.35 & 619.19 & 743.03 & 770.02 & 797.99 & 1.036 \\
\hline $\begin{array}{l}\text { Irkutsk } \\
\text { Region }\end{array}$ & 885.06 & 442.53 & 590.04 & 737.55 & 885.06 & 885.06 & 885.06 & 0.976 \\
\hline $\begin{array}{l}\text { Kemerovo } \\
\text { Region }\end{array}$ & 569.13 & 284.57 & 379.42 & 474.28 & 569.13 & 591.92 & 615.61 & 1.040 \\
\hline $\begin{array}{l}\text { Novosibirsk } \\
\text { Region }\end{array}$ & 1008.18 & 504.09 & 672.12 & 840.15 & 1008.18 & 1168.05 & 1353.27 & 1.159 \\
\hline Omsk Region & 522.42 & 261.21 & 348.28 & 435.35 & 522.42 & 531.07 & 539.86 & 1.017 \\
\hline $\begin{array}{l}\text { Tomsk } \\
\text { Region }\end{array}$ & 236.36 & 118.18 & 157.57 & 196.97 & 236.36 & 286.35 & 346.92 & 1.212 \\
\hline $\begin{array}{l}\text { Tyumen } \\
\text { Region }\end{array}$ & 749.36 & 374.68 & 499.58 & 624.47 & 749.36 & 846.54 & 956.32 & 1.130 \\
\hline $\begin{array}{l}\text { Khanty-Mansi } \\
\text { Autonomous } \\
\text { Area }\end{array}$ & 578.40 & 289.20 & 385.60 & 482.00 & 578.40 & 620.97 & 666.67 & 1.074 \\
\hline Total in IASA & 7229.98 & 3614.99 & 4819.99 & 6024.99 & 7229.98 & 7664.54 & 8125.22 & 1.060 \\
\hline $\begin{array}{l}\text { Total in } \\
\text { Siberian } \\
\text { Federal } \\
\text { District }\end{array}$ & 5846.09 & 2923.05 & 3897.39 & 4871.74 & 5846.09 & 6132.20 & 6432.32 & 1.049 \\
\hline
\end{tabular}

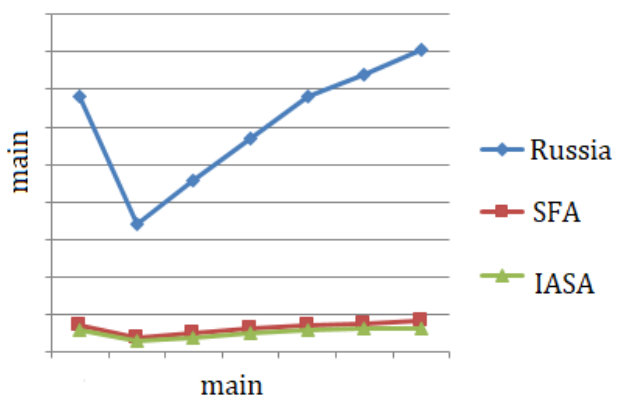

Figure 5 Dynamics of tourist flows in Russia, SFA, and IASA, 2019-2025 (moderate scenario)

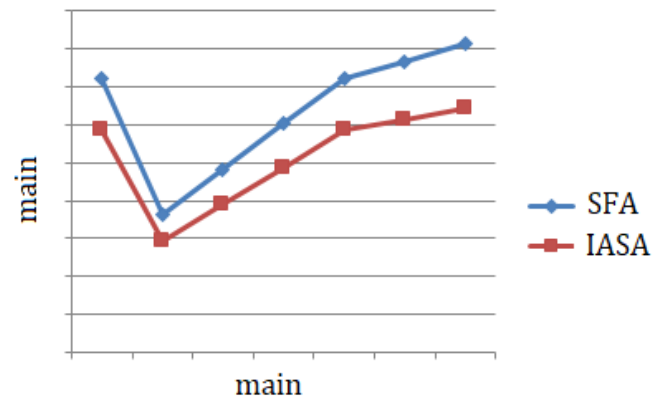

Figure 6 Dynamics of tourist flows in SFA and IASA, 2019-2025 (moderate scenario) 


\subsection{Scenario 4 (positive)}

Calculation algorithm:

$$
\begin{gathered}
\mathrm{P}(2020)=\mathrm{P}(2019)^{*} 0.8 \\
\mathrm{P}(\mathrm{t}+1)=\mathrm{P}(\mathrm{t})+(\mathrm{P}(2019)-\mathrm{P}(2020)) / 5
\end{gathered}
$$

Table 4 Forecast for the size of the tourist flow in the constituent entities of the Russian

\begin{tabular}{|c|c|c|c|c|c|c|c|c|}
\hline Region & 2019 & 2020 & 2021 & 2022 & 2023 & 2024 & 2025 & $\begin{array}{r}\text { Average } \\
\text { growth } \\
\text { index } \\
2015- \\
2019\end{array}$ \\
\hline $\begin{array}{l}\text { Russian } \\
\text { Federation }\end{array}$ & 68283.89 & 54627.11 & 59179.37 & 63731.63 & 68283.89 & 74083.39 & 80375.46 & 1.085 \\
\hline Altai Republic & 193.41 & 154.73 & 167.62 & 180.52 & 193.41 & 196.11 & 198.85 & 1.014 \\
\hline $\begin{array}{l}\text { Republic of } \\
\text { Buryatia }\end{array}$ & 365.92 & 292.73 & 317.13 & 341.52 & 365.92 & 376.84 & 388.10 & 1.030 \\
\hline Tyva Republic & 35.62 & 28.50 & 30.87 & 33.25 & 35.62 & 35.74 & 35.86 & 1.003 \\
\hline $\begin{array}{l}\text { Republic of } \\
\text { Khakassia }\end{array}$ & 163.63 & 130.90 & 141.81 & 152.72 & 163.63 & 165.34 & 167.06 & 1.010 \\
\hline Altai Region & 669.03 & 535.22 & 579.83 & 624.43 & 669.03 & 671.08 & 673.14 & 1.003 \\
\hline $\begin{array}{l}\text { Transbaikal } \\
\text { Region }\end{array}$ & 214.16 & 171.33 & 185.60 & 199.88 & 214.16 & 216.47 & 218.81 & 1.011 \\
\hline $\begin{array}{l}\text { Krasnoyarsk } \\
\text { Region }\end{array}$ & 743.03 & 594.42 & 643.96 & 693.50 & 743.03 & 770.02 & 797.99 & 1.036 \\
\hline Irkutsk Region & 885.06 & 708.05 & 767.05 & 826.06 & 885.06 & 885.06 & 885.06 & 0.976 \\
\hline $\begin{array}{l}\text { Kemerovo } \\
\text { Region }\end{array}$ & 569.13 & 455.30 & 493.25 & 531.19 & 569.13 & 591.92 & 615.61 & 1.040 \\
\hline $\begin{array}{l}\text { Novosibirsk } \\
\text { Region }\end{array}$ & 1008.18 & 806.55 & 873.76 & 940.97 & 1008.18 & 1168.05 & 1353.27 & 1.159 \\
\hline Omsk Region & 522.42 & 417.94 & 452.77 & 487.60 & 522.42 & 531.07 & 539.86 & 1.017 \\
\hline Tomsk Region & 236.36 & 189.09 & 204.84 & 220.60 & 236.36 & 286.35 & 346.92 & 1.212 \\
\hline Tyumen Region & 749.36 & 599.49 & 649.45 & 699.41 & 749.36 & 846.54 & 956.32 & 1.130 \\
\hline $\begin{array}{l}\text { Khanty-Mansi } \\
\text { Autonomous } \\
\text { Area }\end{array}$ & 578.40 & 462.72 & 501.28 & 539.84 & 578.40 & 620.97 & 666.67 & 1.074 \\
\hline Total in IASA & 7229.98 & 5783.99 & 6265.99 & 6747.99 & 7229.98 & 7664.54 & 8125.22 & 1.060 \\
\hline $\begin{array}{l}\text { Total in } \\
\text { Siberian } \\
\text { Federal District }\end{array}$ & 5846.09 & 4676.87 & 5066.61 & 5456.35 & 5846.09 & 6132.20 & 6432.32 & 1.049 \\
\hline
\end{tabular}
Federation-members of IASA until 2025 (positive scenario), thousands of people

Dynamics of tourist flows according to this forecast scenario are shown in Figures 7 and 8.

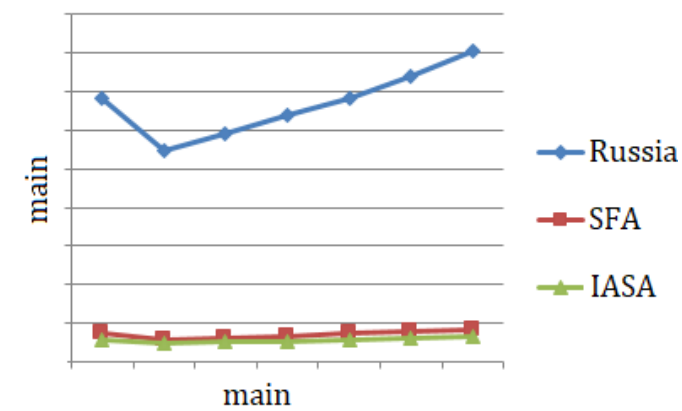

Figure 7 Dynamics of tourist flows in Russia, SFA SFD, and IASA, 2019-2025 (positive scenario)

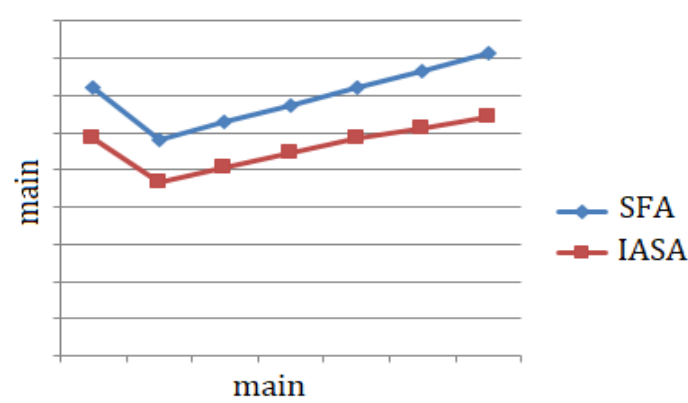

Figure 8 Dynamics of tourist flows in SFD and IASA, 2019-2025 (positive scenario) 
The proposed approach makes it possible to obtain a certain range of forecast estimates for an arbitrary number of scenarios with different initial premises. The simplicity of their change and the low labor intensity of data preparation and calculations make it possible to quickly correct the forecast values with a significant deviation of the real development of events from the initial premises, which is likely for the "new reality." n. Therefore, it is necessary to predict the rate of change that could lead to recovery and subsequent growth in the tourism industry, as well as to have the ability to adjust forecasts in time to match the rate of change. The need for regular adjustments to the forecast requires minimizing the complexity of the applied forecasting tools.

The issue of estimating the forecast error in conditions of high uncertainty is debatable. The method for assessing the error is determined by the purpose of developing a forecast; in this study the aim of forecast is to identify trends in changes in tourist flows in a pandemic $i$. These results are necessary for the development of a draft roadmap for the restoration of tourist flows. The use of methods of scaled or relative errors is possible when statistical data on the dynamics of tourist flows are accumulated for at least a year after the start of the pandemic, which is necessary to study its impact on tourism in different tourist seasons.

\section{Conclusions}

Restoration of tourist flows depends on external global factors related to the safety of tourists and the local population, the possibility of removing restrictive measures on tourists' travel, and the development of measures to support the tourism business at the federal and regional levels. These measures will be more effective if they are balanced precisely in terms of necessary costs and projected results. The pace and weak predictability of changes requires speed and accuracy of managerial decisions, considering the possibility of their adjustment.

By early July 2020, the situation developed under a pessimistic scenario. The decrease in the tourism industry in the Republic of Buryatia in the first quarter of 2020 amounted to $80 \%$ in comparison with the corresponding period of 2019. The Government of the Republic of Buryatia is implementing a wide range of state support measures for small and medium-sized enterprises in the tourism sector to reduce the negative effects and implement opportunities associated with the spread of coronavirus c. Allocated funds in the amount of more than 52 million rubles will be used for implementing support measures, such as granting subsidies to tour operators representing $80 \%$ of the cost of renting premises to provide services for three months, reimbursement to hotels and other collective accommodation facilities representing $80 \%$ of the cost of utilities for three months, and granting subsidies to tour operators to pay for the contract of insurance of civil liability for failure to fulfill obligations under the contract on sale of a tourist product (Tourism, n.d.).

The forecasting results can underlie the development of options for regional programs to support the tourism industry, which will increase the efficiency of spending. If the pessimistic forecast is realized, it will be necessary to ensure the adoption of measures of direct government intervention in the tourism sector.

\section{References}

Aitzhanova, A.E., 2015. Prediction of Income from Sales of Products and Services in the Tourism Industry. Turan University Bulletin, Volume 1(65), pp. 150-156 
Belinskaya, I.V., Chaikovskaya, A.V., 2017. Game Theory as a Way to Increase Competitiveness of Rural Tourism Market Players. Izvestia of St. Petersburg State Agrarian University, Volume 1(46), pp. 218-222

Berawi, M.A., 2020. Empowering Healthcare, Economic, and Social Resilience during Global Pandemic Covid-19. International Journal of Technology, Volume 11(3), pp. 436-439

Berawi, M.A., Suwartha, N., Kusrini, E., Yuwono, A.H., Harwahyu, R., Setiawan, E.A., Yatmo, Y.A., Atmodiwirjo, P., Zagloel, Y.T., Suryanegara, M., Putra, N., Budiyanto, M.A., Whulanza, Y., 2020. Tackling the COVID-19 Pandemic: Managing the Cause, Spread, and Impact. International Journal of Technology, Volume 11(2), pp. 209-214

Forecasts of International Traveller Activity, 2020. Available Online at https://www.tra.gov.au/International/International-Tourism-

Forecasts/international-tourism-forecasts, Accessed on October 13, 2020

Kirillova, S.A., Chernukha, D.S., 2017. Development of Global, National and Regional Tourism: Condition, Trends, Forecasts. Internet Magazine Naukovedenie, Volume 9(6), pp. $1-10$

LeBlanc, C., 2020. How to Model Predictions for Post-COVID-19 Behavior. PRNewes, 05/26/2020. Available Online at: https://www.prnewsonline.com/travelpredictions-coronavirus-apco/, Accessed on October 15, 2020

Losses of Russian Tourism due to Pandemic are Calculated. Available Online at https://www.rosbalt.ru/business/2020/05/15/1843540.html, Accessed on June 13, 2020

Minaev, V.A., Platonova, N.A., Tsyshchuk, E.A., 2015. Regional Tourism: Forecasting and Development Planning in the Current Macroeconomic Environment. Regional Economics: Theory and Practice, Volume 23(398), pp. 2-12

Pershina, E.S., Daragan, S.V., 2018. From Big Data to Advanced Analytics in the Tourism Industry. Scientific Bulletin of MSITI, Volume 2(52), pp. 60-69

Pradita, S.P., Ongkunaruk, P., Leingpibul, T.D., 2020. Utilizing an Intervention Forecasting Approach to Improve Reefer Container Demand Forecasting Accuracy: A Case Study in Indonesia. International Journal of Technology, Volume 11(1), pp. 144-154

Tourism and COVID-19: In Buryatia, the Flow of Tourists Was Reduced by More than Half, 2020. Available Online at https://burunen.ru/news/economy/68885-turizm-i-covid19-v-buryatii-turpotok-sokratilsya-bolee-chem-napolovinu/, Accessed on August 10, 2020 